\title{
COBERTURA JORNALÍSTICA SOBRE DESASTRES NO BRASIL: DIMENSÕES SOCIOPOLÍTICAS MARGINALIZADAS NO DEBATE PÚBLICO
}

\section{News Coverage of the Disasters in Brazil: Concealed Socio-Political Dimensions in the Public Debate \\ Cobertura periodística de los desastres en Brasil: dimensiones sociopolíticas marginalizadas en el debate público}

Norma Valencio, Universidade Federal de São Carlos (Brasil)

norma.valencio@ufscar.br

Arthur Valencio ${ }^{1}$, University of Aberdeen (UK)

a.valencio@abdn.ac.uk

\section{Recibido: abril 15, 2016}

Aprovado: julho 11, 2016

\section{RESUMO}

No Brasil, as Ciências Sociais podem prover a opinião pública com interpretações relevantes sobre desastres, uma vez que dispõem de recursos teóricos e metodológicos apropriados para identificar e interpretar a multidimensionalidade de aspectos sociais envolvidos. Apesar disso, suas contribuições são pouco valorizadas pelos meios de

1 Apoyado por CNPq (Brasil)" 
comunicação de massa que fazem a cobertura jornalística desses acontecimentos trágicos. Através de pesquisa documental quali/quantitativa, esse estudo ilustra alguns aspectos sociopolíticos das crises crônicas - no contexto nacional e, especialmente, no contexto da região Sudeste - e que são pouco explorados pelas reportagens sobre desastres. Conclui-se que, embora haja frequente destaque das crises agudas nos noticiários brasileiros, o conteúdo das notícias perde muito de sua qualidade narrativa quando desconsidera o desastre como um processo social de longa duração e alcance.

Palavras-chaves: desastres, catástrofes, crises, meios de comunicação, Brasil.

\section{ABSTRACT}

The Social Sciences can provide to the public opinion significant interpretations about disasters, once they have the appropriate theoretical and methodological resources to identify and analyse the multiple dimensions of the involved social aspects. Nonetheless, their contributions are underestimated in Brazil by the communication media that covers such tragic events. Following qualitative-quantitative research methods, this study illustrates socio-political aspects of the chronic crisis, which are little explored by the disaster reporting. This is presented for the Brazilian national context, and, in particular, for the South-Eastern Region. The conclusions reveal that, although the acute crisis appear frequently in the news headlines, the content of the news loses narrative quality when it does not consider the disaster as a long-term and large scale social process.

Keywords: Disasters, catastrophes, crisis, media communication, Brazil.

\section{RESUMEN}

Las ciencias sociales pueden proveer a la opinión pública interpretaciones significativas sobre los desastres, toda vez que disponen de los recursos teóricos y metodológicos para identificar y analizar las múltiples dimensiones de los aspectos sociales involucrados. A pesar de esto, sus contribuciones son subestimadas en Brasil por los medios de comunicación que cubren tales tragedias. A través de métodos cualitativos y cuantitativos, este estudio ilustra los aspectos sociopolíticos de las crisis crónicas, que son poco explorados por los reportajes sobre desastres. Esto se presenta en el contexto nacional y, especialmente, en la región sudeste. Las conclusiones revelan que, a pesar de que la crisis aguda aparece frecuentemente en los titulares de las noticias, el contenido de las noticias pierde su calidad narrativa cuando no es considerado el desastre como un proceso social a largo plazo y a gran escala.

Palabras clave: desastres, catástrofes, crisis, medios de comunicación, Brasil. 
Na perspectiva das Ciências Sociais, há uma pluralidade de compreensões sobre o que seja um desastre e a busca de consenso tem obtido resultados infrutíferos. Apesar disso, há algumas convergências interpretativas e complementariedades interessantes no debate em torno da definição do que seja um desastre: tratar-se-ia de ocorrências trágicas que se desenrolariam num tempo social (Sorokin, 1942); um estresse coletivo relacionado a rupturas súbitas, múltiplas e concentradas na dinâmica da vida social de um dado grupo (Fritz, 1961); seria um tipo de evento crítico (Das, 1995); uma ocasião súbita, na qual uma séria ruptura de rotinas coletivas e perdas significativas levariam a uma inesperada mudança das histórias de vida (Quarantelli, 2005). Diria respeito, ainda, a uma circunstância de experimentação coletiva, súbita e involuntária de danos e prejuízos multidimensionais, os quais inviabilizariam aos sujeitos afetados terem as devidas condições de manter minimamente as suas rotinas da vida cotidiana (Valencio, 2014), caracterizando-se como um tipo de episódio em que há uma "quebra do acontecer" (Gaitán, Lozano, \& Piñuel, 2013).

As contribuições crescentes e diversificadas de estudiosos das Ciências Sociais ao tema dos desastres trazem repertórios alternativos e instigantes, os quais poderiam ser apresentados ao grande público se houvesse a devida demanda dos meios de comunicação para tal. Se isso ocorresse, talvez aumentassem as chances do público se interessar por dimensões recônditas da estrutura e da dinâmica social que estão na origem deste problema. Quiçá se desencadearia um efervescente debate público, num oportuno contrabalanço ao peso hegemônico das narrativas inspiradas nas ciências duras e da natureza, que tanto supervalorizam as peculiaridades de agentes físicos desencadeadores de desastres (tempestades, enchentes, deslizamentos de terra e outros) e as soluções técnicas correspondentes (monitoramento do tempo e clima, produção de mapas de risco, implantação de sistemas de alerta e afins). Sendo o meio social o core de um desastre, seria de esperar que a prática midiática corrente - dos veículos de massa àqueles dirigidos à divulgação científica - não aceitasse reducionismos interpretativos sobre esse aspecto; mas, desafortunadamente, isso é o que mais tem ocorrido. A visão dominante mantém opaco o processo social desencadeador de desastres, no qual crises sociais agudas e crônicas se misturam.

Entre os cientistas sociais, há um relativo consenso de que os desastres possam ser considerados como um tipo de crise (Quarantelli, Lagadec, \& Boin, 2007), ou melhor, como um contexto do qual deriva e no qual emerge um somatório de crises. Estas corresponderiam às incapacidades/limitações/dificuldades sociais - de caráter cultural, econômico, político e afins - dos sujeitos envolvidos em lidar com certos fatores de ameaça. Disso resultariam graves rupturas nas rotinas sociais, as quais passariam a exigir práticas de reparações urgentes para mitigar os danos decorrentes (Boin e t' Hart, 2007). Mas, há estudiosos que fazem uma distinção entre desastre e crise. 0 desastre evidenciaria que o fator deflagrador não teria sido intencional e que as medidas de resposta contariam com uma disposição social colaborativa entre os atores envolvidos enquanto que as crises seriam caracterizadas por conflitos sociais (Quarantelli, 2005).

Nos estudos voltados para a realidade latino-americana, a identificação de disposições sociais cooperativas no contexto de desastre - principalmente, em termos intracomunitários e das práticas das redes informais de ajuda - não obnubila a fartura de conflitos sociais, de caráter estrutural, que favorecem tanto a proliferação quanto a duração alargada dessas ocorrências (Cortes, 2005; Valencio, 2012; Siena, 2013). Grupos sociais que 
vivem sob condições habitacionais e de trabalho precárias e insalubres, radicados em áreas com infraestrutura urbana e rural suscetível, estão imersos em um processo histórico de vulnerabilização e, portanto, mais predispostos a sofrer as graves consequências de inundações e deslizamentos de terra (Acselrad, 2002; 2006; 2015). Até mesmo os saques que ocorrem nessas ocasiões poderiam ser analisados sob um ângulo da contestação social dos grupos afetados num desastre e mal atendidos pelo ente público e, portanto, interpretados de modo diverso da abordagem legalista que criminaliza os seus praticantes (Marchezini, 2014; Roca, 2014).

A insuficiência das medidas recuperativas acionadas pelo Estado, em prol de grupos sociais afetados num desastre, prolonga demasiadamente o sofrimento dos mesmos, numa deterioração objetiva e subjetiva da sua existência. Isso se desenrola num tempo social que suplanta o tempo cronológico da emergência decretada oficialmente, do que resulta que estes grupos fiquem suscetíveis a novos riscos (Vargas, 2015; Valencio, 2015). Ademais, como fartamente ilustrado em casos contemporâneos - como o da passagem do furacão Katrina por New Orleans, em 2005 - os critérios de preparação, resposta e recuperação adotados pelo meio técnico e autoridade governamental, podem ser ostensivamente discriminatórios e inviabilizar que os grupos sociais considerados inferiores obtenham a devida proteção preventiva ou, após os danos e perdas sofridos, consigam o apoio adequado para restaurar suas rotinas (Bullard, 2006; Oliver-Smith, 2006; Tierney et al, 2006).

As Ciências Sociais dispõem de um farto repertório científico para balizar o discurso midiático quando defronte a esses contextos críticos. Porém, os meios de comunicação hegemônicos produzem e difundem informação ao largo dessa possibilidade de contribuição científica e se mantêm focados na imprevisibilidade das forças da natureza ou em dramas individuais interpretados de um modo estereotipado. É como se o processo social implicado inexistisse. Isso não se deve à deficiências de formação jornalística. $O$ estudo de questões sociais está entranhado na profissionalização do jornalista; mas, tudo se passa como se a atuação desse profissional na cobertura de desastres, em várias partes do mundo, pudesse prescindir desse repertório e não houvesse alternativa senão insistir em fórmulas mais sensacionalistas do que analíticas (Scanlon, 1996). Há razões instrumentais subjacentes a tal escolha: a adoção padronizada da dramaticidade socialmente acrítica tem sido eficaz para fidelizar um amplo segmento da opinião pública (Scanlon, 2007; 2011) que se vê, ambiguamente, atemorizado e obcecado por informações abundantes sobre riscos múltiplos e simultâneos ao seu derredor (Beck, 1999).

Num mercado em que a notícia em primeira mão é algo que conta na disputa de audiência, os meios de comunicação são premidos pelo tempo e, assim, se mantêm aferrados às fórmulas convencionais de sucesso. Dentre elas, a da espetacularização dos desastres (Alexander, 2005), que apela para o suspense - por exemplo, focalizando a fragilidade de algumas vítimas em risco iminente à vida e a bravura de quem as resgata - ou para a compaixão, destacando as ações voluntárias voltadas para a reabilitação dos grupos mais prejudicados no acontecimento. Porém, fórmulas fáceis cobram um alto preço do público, pois o entretém sem esclarecer o processo social desencadeador da situação desoladora.

Como pesquisadores empíricos e documentais, focados em investigação sociológica in loco, bem como nos registros oficiais sobre desastres, tomamos contato assistemático e não intencional com a cobertura jornalística sobre os casos nos quais estávamos nos detendo cientificamente. Deparamo-nos com uma profusão de matérias jornalísticas, difundidas através de diferentes veículos, nas variadas situações de campo em que nos encontrávamos, uma vez que o desastre em curso era o assunto principal em voga, do âmbito local ao nacional. Durante o deslocamento rodoviário ao cenário da tragédia, era disso que tratava o noticiário radiofônico que acompa- 
nhávamos no carro que nos conduzia; durante o descanso no hotel, na localidade onde realizávamos a coleta de dados primários, ligávamos a televisão e o noticiário se detinha exaustivamente no caso; em exemplares de jornais impressos, expostos em bancas locais ou mesmo oferecidos por algum de nossos sujeitos pesquisados, a manchete não deixava dúvidas sobre a importância do caso que ali ocorria; ao abrir um site de notícias, na internet, ali estava destacada a mesma ocorrência. Essa exposição constante ao teor de inúmeras matérias no assunto permitiu observar que o mesmo era recorrentemente evocado, em termos jornalísticos, em aspectos bastante distintos - senão mesmo, opostos - daqueles que a nossa pesquisa sociológica apontava.

Enquanto nos esforçávamos em criticar os processos tecnicamente denominados como "remoção de famílias" das ditas "áreas de risco" (Valencio, 2009), matérias jornalísticas banalizavam essa prática (Solano, 2009), (O Estado de São Paulo, 2016). Enquanto chamávamos a atenção da comunidade científica para a maior suscetibilidade de municípios brasileiros de porte demográfico pequeno (Valencio e Valencio, 2011), e mostrávamos o abandono social dos grupos afetados nos desastres (Valencio, Siena \& Marchezini, 2011), as notícias exaltavam os sistemas de monitoramento e alertas que estavam sendo implantados e não problematizam os critérios adotados nessa medida técnica (Folha de São Paulo, 2011). Enquanto questionávamos a utilização pública da terminologia "desastre natural" (Valencio, 2014), esta se mantinha como classificação usual da ocorrência nos principais jornais de circulação nacional, que também insistiam em dizer que as chuvas é que matavam (Balza, 2008); (G1, 2010a); (G1, 2010b); (Folha de São Paulo, 2010) e assim por diante. Isso foi um ponto de partida para identificarmos - em caráter preliminar, informal, porém ao longo de uma década - a desconexão interpretativa entre a análise sociológica que empreendíamos e a interpretação jornalística mais corrente na cobertura de desastres no Brasil. Resultados de pesquisa de outros cientistas sociais que acessávamos, pareciam igualmente não reverberar no discurso midiático dominante. As matérias jornalísticas que chegavam pelas vias ordinárias da nossa vida cotidiana, não apenas estavam balizadas por outro universo de significados mas, em seu conjunto, amalgamavam representações sociais reducionistas sobre a realidade social. Um sintoma disso era que, quando convidados por algum veículo para nos manifestar sobre tal ou qual desastre de grande repercussão - em programas de televisão, de rádio, jornais ou blogs de jornalistas e outros -, gastávamos mais tempo em criticar a pré-concepção do entrevistador e situá-lo minimamente em nosso universo interpretativo do que nos debruçar no caso em si. Uma vez aberto à perspectiva nova que ali descortinávamos o entrevistador não a descartava de todo. Talvez por isso, cremos que nossa insistência em apresentar uma interpretação sociológica sobre desastre a jornalistas, não seja algo em vão.

Tendo em consideração tal problemática, esse texto se caracteriza como um ensaio de natureza sociológica, dedicado tão somente a sintetizar as preocupações similares de iminentes estudiosos em desastres e expor, como eixo principal, os resultados de pesquisa sociológica sobre registros oficiais (decretos municipais) de desastres ocorridos no Brasil nos últimos anos. Assim, não se trata de um estudo na área de comunicação e tampouco houve intento de se debruçar, de maneira sistemática, sobre matérias jornalísticas para servir de evidência irrefutável em comprovação à cisão acima mencionada. Nesse particular, fizemos apenas a demarcação inicial acima e trouxemos ilustrações do problema. A contribuição pretendida está nos resultados da pesquisa sobre os decretos municipais de emergência e julgamos que, a par disso, os estudiosos em comunicação possam, eventualmente, vir a fazer o caminho inverso, isto é, com seus métodos próprios, venham comprovar ou refutar as desconexões mencionadas. 
Dito isso, e após um breve panorama do debate que apresentamos logo abaixo, passamos a descrever e analisar aspectos do contexto contemporâneo brasileiro de produção social de desastres. Demos destaque aos desastres ocorridos na região Sudeste do país, formada pelas unidades federativas do Espírito Santo, Minas Gerais, Rio de Janeiro e São Paulo.

\section{Estado da arte}

Quando a opinião pública suspeita que os meios de comunicação seguem um roteiro padronizado crise após crise (Scanlon \& Alldred, 1982), utilizado desde a cobertura de desastres ditos "naturais" até aos atentados terroristas, essa prática corre o risco de perder sua eficácia. Eventualmente, a opinião pública extenuada com esse apelo midiático repetitivo pode se tornar gradualmente menos receptiva e desinteressada pelas histórias individuais que focalizam o "exato instante" em que algo surpreendente ou maléfico ocorreu (Scanlon, 1996; 2011), uma vez que as mídias sociais oferecem maior instantaneidade na disseminação desse tipo de informação (Alexander, 2014). Algo mais substantivo deveria, portanto, ser o diferencial do jornalismo profissional, já que as velhas fórmulas, ora atualizadas, podem ter seus dias contados diante às câmeras individuais de pessoas comuns, que capturam cenas inusitadas e compartilham imagens e significados. Também não será por meio da crescente abertura dos meios de comunicação institucionais para recepcionar e divulgar uma fartura de imagens autorais e amadoras que a opinião pública estará devidamente informada sobre a trama social que delineia um desastre.

Saltos de qualidade poderiam ser dados em duas ou mais direções alternativas e mais promissoras, a fim de recapturar a parcela do público mais exigente e saturada com as fórmulas convencionais. Um dos caminhos a que estudiosos se referem é o da imprensa procurar se embasar mais em relação aos preceitos técnicos de emergência e, assim, se tornar uma grande aliada para difundir recomendações de prevenção, avisos de evacuação e esclarecer rumores, entre outras práticas cooperativas (Scanlon, 1996, 2007); (Alexander, 2014); (Iqbal et al, 2014). No entanto, cada contexto social específico pode apresentar diferentes vantagens e desvantagens nessa aliança.

No contexto brasileiro, suspeitamos que esse caminho seja temerário, porque pode favorecer com que a imprensa assimile, difunda e reforce visões do meio técnico-operacional que são contaminadas por uma racionalidade autoritária e um habitus militar, que frequentemente não se coadunam com as visões das comunidades vulnerabilizadas com as quais esses atores estatais interagem. Se a imprensa for parcial e pender para a visão oficial, tomando-a como uma totalidade, os atores sociais que estão no centro da crise - aqueles que efetivamente sofreram as perdas e danos involuntários -, não conseguem expressar sua perspectiva sobre os fatos que modificaram, substantivamente e para pior, suas vidas. Os atores dominantes acabam difundindo privilegiadamente não apenas o seu olhar sobre o problema, mas também sobre as soluções a serem adotadas, o que pode ser considerado como um tipo de violência contra os grupos afetados, os quais se sentem socialmente silenciados e subjugados (Das, 1995). A fala autorizada adota práticas de tergiversação para que, ao mesmo tempo em que mostre domínio de variados aspectos do problema, não deixe o leitor perceber a sua responsabilidade no episódio e na implementação de soluções que não foram tomadas a tempo e geraram aquela tragédia (Amaral, 2015). As escolhas midiáticas por certos interlocutores interferem no "campo" (Bourdieu, 2004), onde há conflitos e sufocamentos de interpretações discordantes acerca dos fatos trágicos. 
A disposição para pender empaticamente para a fala autorizada, a do meio técnico-operacional que atua nas emergências, oferece ganhos dos quais os meios de comunicação não quererão abrir mão tão facilmente. Um deles é o tornar suas equipes de reportagem confiáveis pelos técnicos de emergência, tanto para participarem das missões de alta periculosidade, consoante com o objetivo de produzir uma maior espetacularização em torno do acontecimento, quanto para compartilharem, em primeira mão, informações restritas que se tornarão furos de reportagem. Em contrapartida, os meios de comunicação colaboram com a falsa impressão de que há uma instantaneidade de sua inserção no ápice dos acontecimentos, como se tivessem sido os primeiros a chegar ao lugar afetado. Junto a isso, os serviços de emergência e as vítimas, como se estivessem passivamente à espera de assistência externa ou de priorizar contar a sua história diante das câmaras ou gravadores, ao invés de se cuidarem (Quarantelli, 1989). Os meios de comunicação, que participam desse acordo tácito com o meio técnico-operacional, colaborariam com a difusão de discursos pasteurizados que repreendem a tudo e todos que pareçam dissonantes, numa ordem social idealizada, que teria sido rompida com a plena manifestação do risco. Deste modo, uma cultura repressiva é que fortalece e desencadeia outras práticas, como a do alarde jornalístico à pretensa eficácia de sistemas de vigilância, de múltiplos monitoramentos e de alertas. Na captura de imagens surpreendentes, as reportagens convocam a curiosidade do público e, aproximando-o do cenário repleto de perigos e desolação, tende a replicar os sentidos interpretativos dominantes (Gaitán, Lozano \& Piñuel, 2013). Nessa composição, de palavra e imagem, ocorre a atenuação de alguns sinais e o fortalecimento de outros, como parte constitutiva de um processo de amplificação (Kasperson et al, 1988) que penetra no sistema social e influencia no funcionamento das sociedades e os jogos de poder (Roze, 2016). Desse pacto, participam grupos científicos convergentes com a ideia hegemônica de ordem social. Quando abordados pela imprensa, estes pesquisadores aproveitam a oportunidade para difundirem discursos de intolerância, já presentes em seus estudos, voltados àqueles que "insistem" em se expor aos riscos e precisam ser "conscientizados" para terem uma "percepção ambiental" mais apropriada em relação a seu contexto de inserção (Acselrad, 2006; Cardoso, 2006).

Ainda que visões mais estreitas de ordem social e normalidade possam, eventualmente, prevalecer, isso não condiz com as formas complexas como o mundo realmente funciona. Tem havido uma crescente percepção pública de que a imprensa mainstream, que cobre desastres de um modo estereotipado, adota focos condizentes com os de classes privilegiadas enquanto ignora totalmente outros que seriam do interesse de grupos marginalizados. Ademais, a cobertura excessiva na crise aguda contrasta com o esquecimento do assunto algum tempo depois, quando as medidas de recuperação ainda são insuficientes e mereceriam uma pauta (Biernacki, 2013); (Shah, 2005).

É pelas margens da sociedade, quando consideradas, que o entendimento sobre a obscuridade das estruturas políticas e econômicas, os limites entre o legal e o ilegal, tende a se clarificar (Das \& Poole, 2008). Nos espaços marginais, as interações sociais ganham outros significados e se desenrolam de um modo diferenciado (Bauman, 2011). Portanto, é de supor que os episódios de desastres que envolvam esses espaços de exclusão - onde as ocorrências são mais frequentes no Brasil - decorram de uma forma diferenciada em relação ao que ocorreria nos espaços plenamente integrados. Porém, jornalistas movidos por visões preconcebidas não conseguem captar as feições deste problema, sob um ângulo favorável aos grupos afetados, que estão numa posição desfavorável no campo de disputas, isto é, não conseguem adotar uma perspectiva coadunada com a multidimensionalidade do sofrimento social ali presente. 
Se os meios de comunicação desejassem ancorar o seu capital social numa cobertura mais aprofundada sobre desastres - como de resto, em relação a demais temas de interesse social -, suas equipes seriam mobilizadas a dar um passo mais além do mero acontecimento pontual que ora as fascina. Esse distanciamento é algo desafiador, pois exige problematizar o acontecimento que "quebrou a inércia da vida" (Martín-Barbero, 2002). É dizer, isso implicaria adotar certa permeabilidade para admitir como legítimas as inúmeras representações sobre a tragédia, incluindo aquelas que fossem incompatíveis com a visão dominante, até então, privilegiada nas reportagens convencionais nesse tema.

\section{Metodologia}

Alguns números oficiais da defesa civil sobre a trajetória dos desastres no Brasil dão pistas de uma dimensão sociopolítica que vai além de cada acontecimento em particular. Isto é, podem sinalizar a crise crônica subjacente às crises agudas pontuais que são mais usualmente exploradas na abordagem midiática no tema.

Apresentamos, primeiramente, resultados sintéticos de pesquisa documental, na qual houve coleta, sistematização e análise sociológica de informações quantitativas - do total nacional e da Região Sudeste - dos decretos municipais de Situação de Emergência (SE) e de Estado de Calamidade Pública (ECP), provenientes das portarias ministeriais de reconhecimento desses atos administrativos locais. A coleta foi virtual, uma vez que a referida informação é pública e encontra-se disponível no site da Secretaria Nacional de Proteção e Defesa Civil do Ministério da Integração Nacional, bem como pode ser consistida junto ao Diário Oficial da União, no site da Imprensa Nacional. Os mencionados decretos são emitidos pelas prefeituras municipais, no geral, a partir dos subsídios de sua respectiva Coordenação Municipal de Defesa Civil ou congênere, a qual se baseia num sistema de classificação de desastre elaborado no nível federal de governo. Até o ano de 2012, tratava-se do Código de Desastres, Ameaças e Riscos - CODAR, tendo sido desde então substituído pelo Código Brasileiro de Desastres - COBRADE. Os decretos municipais seguem para o Governo Federal, a fim de que sejam reconhecidos pela autoridade nacional através de Portarias de Reconhecimento do Ministério da Integração Nacional, emissão esta que, uma vez publicada no Diário Oficial da União, lastreia legalmente as variadas medidas públicas de caráter excepcional, que passam a ser tomadas pelas autoridades governamentais locais, particularmente, a aquisição sem licitação pública de serviços de terceiros, de equipamentos e de bens de primeira necessidade, relacionados às ações emergenciais de resposta.

O período principal focalizado foi o dos últimos 13 anos (2003-2015) e abrangeu desde o início do $1^{\circ}$ mandato do governo Lula (iniciado em $1^{\circ}$ de janeiro de 2003) - quando as informações sobre SE e ECP passaram a ser disponibilizadas com maior regularidade, em consonância com a melhor assimilação técnica do sistema de classificação CODAR, e do formulário de Avaliação de Danos (AVADAN), lançados na Política Nacional de Defesa Civil de 1995, durante a gestão presidencial de Fernando Henrique Cardoso, até o $2^{\circ}$ mandato do governo Dilma Rousseff (iniciado em $1^{\circ}$ de janeiro de 2015). A partir do panorama nacional dos desastres oficialmente reconhecidos no mencionado período, voltamo-nos especificamente ao panorama da região Sudeste para problematizar que os desastres não são um problema de falta de desenvolvimento, mas resultado de um tipo de desenvolvimento que mantém desigualdades sócioespaciais estruturais. Tais situações são também reflexos dos atores e conhecimen- 
tos ambientais dominantes, que pautam as políticas públicas e hostilizam os atores e repertórios de conhecimentos, que reivindicam concepções alternativas e inclusivas de bem-estar (Acselrad, 2014).

Em seguida, complementamos sucintamente a análise dos dados oficiais com uma síntese de resultados de estudos de casos emblemáticos sobre desastres ocorridos no mesmo período, a fim de apontar outras importantes características da interação social cronicamente conflituosa entre o meio social vulnerabilizado e os serviços técnicos e autoridades políticas que atuam na emergência e no processo de recuperação.

Por fim, a título meramente ilustrativo, mencionamos alguns aspectos do discurso midiático - em reportagens de veículos de abrangência nacional e regional - referidos a casos tratados acima. O propósito foi o de exemplificar o gap entre o teor da cobertura jornalística brasileira e o teor de estudos críticos em Ciências Sociais no tema dos desastres, o que indica uma disposição acomodada - portanto, conservadora - da imprensa, no que concerne ao campo político de sentidos da crise, o que poderia ser objeto de estudos posteriores em comunicação.

\section{Resultados}

As decretações municipais de desastres, seguidas de portaria de reconhecimento do Governo Federal, não devem ser confundidas com um espelho fidedigno da realidade concreta, mas apenas tratadas como uma expressão da visão oficial sobre os acontecimentos. Apesar disso, são informações valiosas para localizar, em termos quantitativos, o patamar contemporâneo brasileiro de uma crise crônica formada por um conjunto de crises agudas.

Para a Secretaria Nacional de Proteção e Defesa Civil, desastre é definido como uma relação entre eventos adversos e um ecossistema vulnerável, o que resulta em danos e prejuízos humanos, materiais e ambientais (Brasil, 2000). Uma Situação de Emergência (SE) é considerada como um desastre de menor monta, isto é, como uma situação anormal em que houve "danos suportáveis" à comunidade afetada, segundo a ótica das autoridades; mas, no geral, esses danos não são assim tão suportáveis aos grupos afetados, que não conseguem se reabilitar e se recuperar a contento. Já o Estado de Calamidade Pública (ECP) é considerado como uma situação anormal na qual os danos mais sérios havidos não conseguem ser mitigados a contento pela própria comunidade afetada ou pelas ações técnicas locais de emergência (Valencio, 2012). Portanto, seja no caso de SE ou de ECP, seria de supor que a prioridade do ente público fosse a restauração mínima das rotinas da vida cotidiana dos grupos afetados e o apoio aos mesmos na recomposição do seu bem-estar, já que a vivência dolorosa do episódio anuncia a necessidade de um recomeço moroso, sofrido e aflitivo. Uma miríade de privações inesperadas e simultâneas torna muitos dos danos e perdas insuperáveis aos afetados. Portanto, as medidas de cuidado humano, deflagradas pelo Estado, deveriam ser o centro de sua ação. Mas isso, lamentavelmente, não ocorre.

Em tese, tais circunstâncias adversas deveriam ser algo excepcional na vida de uma sociedade; isto é, serem um fato tão marcante - devido ao amplo leque de desafios materiais, ambientais, sociais, políticos e emocionais a superar - que exigiria a adoção de medidas de recuperação simultaneamente preventivas, para que nada similar voltasse a ocorrer no futuro. No entanto, no contexto brasileiro, as autoridades municipais decretam emergências com certa regularidade, como se o desmanche das rotinas coletivas - em especial, a dos grupos sociais à margem do processo dominante de produção social do espaço - fosse algo banal.

Ao longo do período 2003-2015, o Brasil manteve um patamar anual superior a mil decretações municipais de desastres, reconhecidas por portaria federal. Num universo de 5.565 municípios e em números médios anuais, 
seria como se 36,09 \% do total de municípios brasileiros passassem por essa provação. Em alguns anos recentes - como os de 2005, 2007, 2009 e 2013 -, o incremento de casos de desastres foi ainda mais expressivo chegando a, respectivamente, 1.818, 1.738, 2.315 e 3.655 decretações. Os dados abaixo assinalam, ainda, uma mudança ascendente do padrão dessas crises: até o ano de 2008, foram menos de dois mil decretos/ano; a partir de 2009, ultrapassou-se essa quantidade, entretanto, os desastres ficaram abaixo de 2.500 decretos/ano; mas, do ano de 2012 em diante, o patamar médio foi o de 2.961 decretos anuais, isto é, seria como se mais da metade dos municípios brasileiros (mais especificamente $53,21 \%$ do total) passasse por excepcionalidade. Portanto, a crise se tornou 0 novo padrão de normalidade (figura 1).

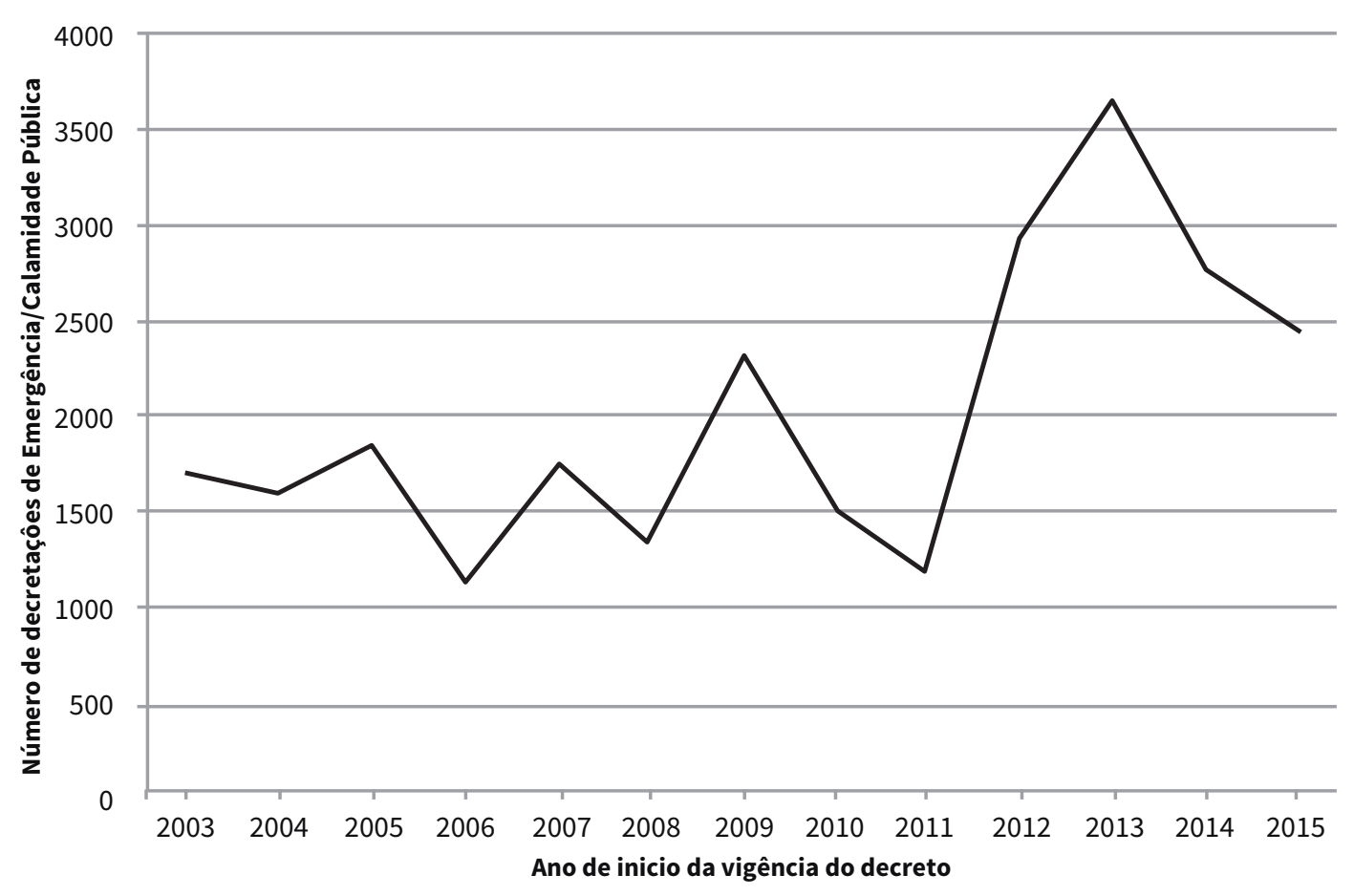

Figura 1: Evolução do número de decretações municipais de Situação de Emergência (SE) e de Estado de Calamidade Pública (ECP) no Brasil, reconhecidos por portaria do Governo Federal, 2003-2015.

Fonte: sistematizado pelos autores a partir de informações da Secretaria Nacional de Proteção e Defesa Civil da República Federativa do Brasil, 2016 (http://www.mi.gov.br/web/guest/ reconhecimentos-realizados, atualização da página: 11/03/2016, acesso: 14/03/2016).

A região Sudeste - compreendida pelos estados do Espírito Santo, Minas Gerais, Rio de Janeiro e São Paulo - é considerada a mais desenvolvida do país em termos tanto econômicos (segundo o Produto Interno Bruto - PIB) quanto sociais (segundo o Índice de Desenvolvimento Humano - IDH). No entanto, nesta região, a decretação municipal de SEs e ECPs ocorre frequentemente e, em alguns casos, é algo recorrente num mesmo município. 
A insuficiência na resolução de um desastre acaba sendo, em grande medida, a causa da ocorrência do desastre seguinte, pois o espaço ainda se encontra suscetível. Nele, os grupos sociais afetados podem ser os mesmos devido, sobretudo, à incapacidade econômica de autoprovimento de meios adequados de proteção, associada à falta de apoio público adequado. Assim, se vistos como processos, os desastres inumeráveis e sucessivos nesses espaços desenham uma espiral de desfiliação social.

Ao longo do período 2003-2014, três a mais decretações municipais de emergência foram expedidas em 204 municípios de Minas Gerais (23,92 \%, do total estadual), em 56 municípios do Espírito Santo ( $71,79 \%$, do total estadual), em 28 municípios do Rio de Janeiro (30,43\%, do total estadual), e em 17 municípios de São Paulo (2,64 \%, do total estadual) (figuras 2 e 3 ). Há um espraiamento quase que generalizado do problema no contexto capixaba e no contexto fluminense, pois $1 / 3$ dos municípios dessas unidades federativas vivenciam a repetição dessas tragédias. Ademais, 63 municípios da região Sudeste - sendo 62 pertencentes ao estado de Minas Gerais e 1 pertencente ao estado do Espírito Santo - decretaram emergência 13 vezes no período de 2003-2015, isto é, uma média de uma emergência por ano (tabela 1). Então, aquilo que deveria ser entendido como um acontecimento social excepcional, tornou-se uma regularidade para tais municípios.

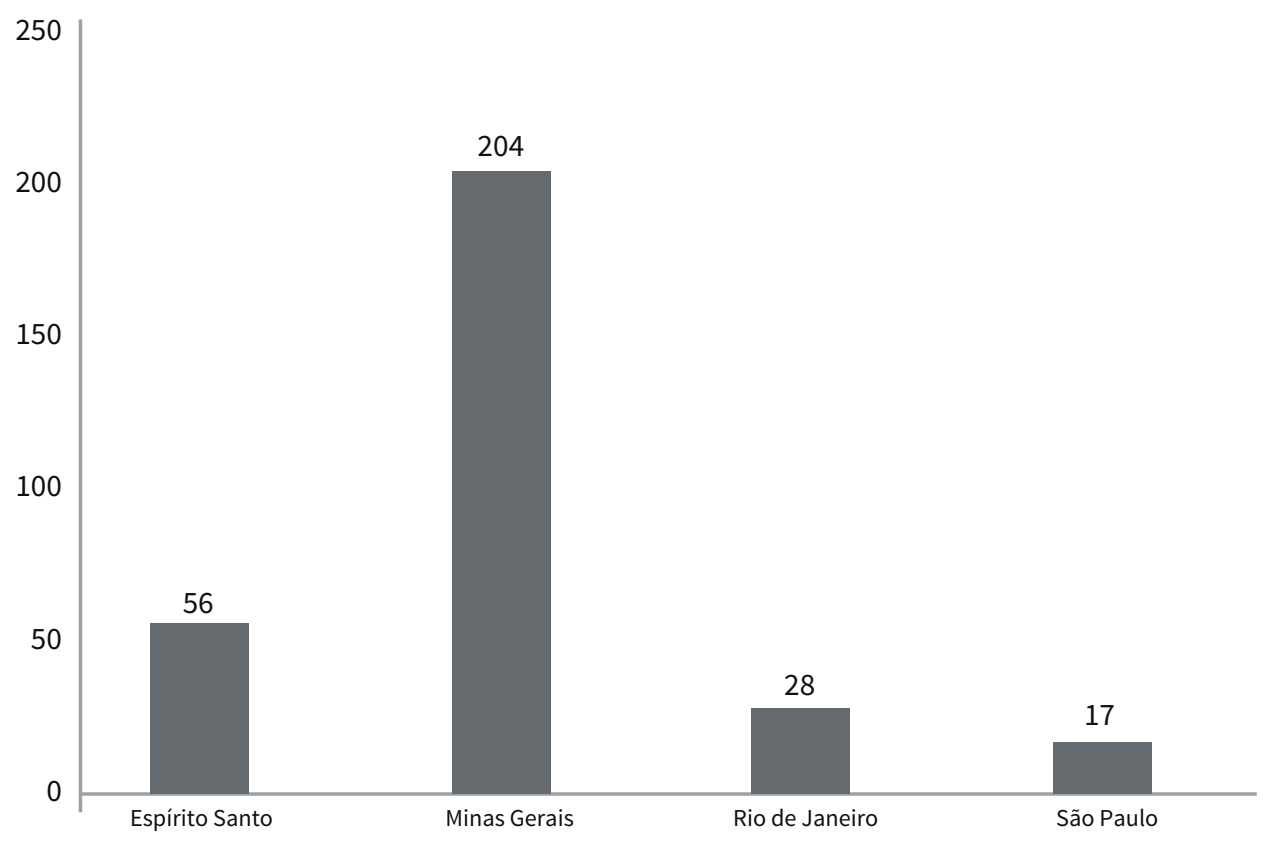

Figura 2: Número absoluto de municípios com decretação recorrente de Emergência/Calamidade Pública (acima de 3 ocorrências/município) por Unidade Federativa da Região Sudeste, 2003-2015.

Fonte: sistematizado pelos autores a partir de informações da Secretaria Nacional de Proteção e Defesa Civil da República Federativa do Brasil, 2016 (http://www.mi.gov.br/web/guest/ reconhecimentos-realizados, atualização da página: 11/03/2016, acesso: 14/03/2016). 


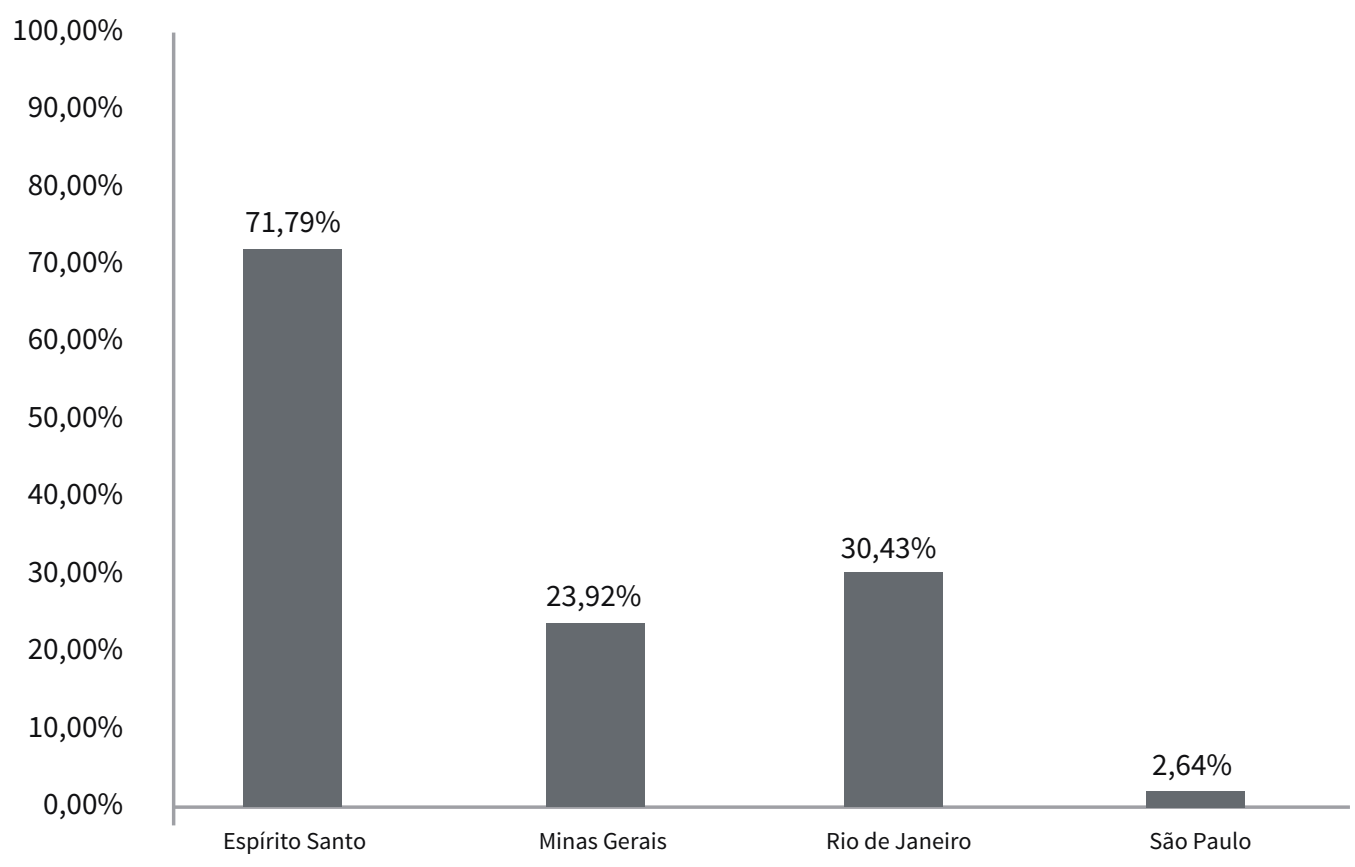

Figura 3: Percentual de municípios com decretação recorrente de SE/ECP (acima de 3 ocorrências/ municípios), relativo ao número de municípios de cada Unidade Federativa da Região Sudeste, 2003-2015.

Fonte: sistematizado pelos autores a partir de informações da SEDEC/MI, 2016 (http://www. mi.gov.br/web/guest/reconhecimentos-realizados, atualização da página: 11/03/2016, acesso: 14/03/2016).

Tabela 1: Municípios da Região Sudeste com total de decretações de Situação de Emergência ou Estado de Calamidade Pública superior a 13 ocorrências no período 2003-2015 (média de 01 ocorrência/ano)

Número de decretações

\section{Municípios}

19

18

17

16

15

Campo Azul/MG, Ibiaí/MG e São Francisco/MG.

Espinosa/MG.

Catuti/MG, Claro dos Poções/MG, Francisco Badaró/MG, Francisco Sá/MG, Jequitaí/MG, Lagoa dos Patos/MG, Luislândia/MG, Monte Azul/MG, Pai Pedro/MG e Ubaí/MG.

Comercinho/MG, Engenheiro Navarro/MG, Gameleiras/MG, Icaraí de Minas/MG, Janaúba/MG, Jenipapo de Minas/MG, Josenópolis/MG, Taiobeiras/MG.

Bonito de Minas/MG, Brasília de Minas/MG, Coração de Jesus/MG, Cristália/MG, Grão Mogol/MG, Pedras de Maria da Cruz/MG, Porteirinha/MG, Salinas/MG e Verdelândia/MG. 
Araçuaí/MG, Arinos/MG, Bocaiúva/MG, Capitão Enéas/MG, Chapada Gaúcha/MG, Francisco Dumont/ 14 MG, Glaucilândia/MG, Guaraciama/MG, Ibiracatu/MG, Indaiabira/MG, Itacambira/MG, Itacarambi/MG, Mamonas/MG, Mirabela/MG, São João da Ponte/MG, Urucuia/MG, Vargem Grande do Rio Pardo/MG, Virgem da Lapa/MG e Vargem Alta/ES.

13

Coronel Murta/MG, Fruta de Leite/MG, Itamarandiba/MG, Joaquim Felício/MG, José Gonçalves de Minas/MG, Manga/MG, Matias Cardoso/MG, Mato Verde/MG, Pintópolis/MG, Rio Pardo de Minas/MG, São João do Paraíso/MG, Várzea da Palma/MG e Itapemirim/ES.

Fonte: sistematizado pelos autores a partir de informações da Secretaria Nacional de Proteção

e Defesa Civil da República Federativa do Brasil, 2016 (http://www.mi.gov.br/web/guest/

reconhecimentos-realizados, atualização da página: 11/03/2016, acesso: 14/03/2016).

Os desastres que se proliferam no país estão associados à água. O mesmo ocorre na região Sudeste, onde a débil capacidade da gestão pública para lidar com as variações de disponibilidade hídrica tem ocasionado sucessivas deflagrações de emergências. Entre desperdícios de água tratada, cobertura sanitária limitada, sistemas de drenagem subdimensionados e uma distribuição iníqua do recurso, as decretações de emergência fornecem respaldo ao ente público apenas para prover um amortecimento circunstancial dos danos socialmente mais insuportáveis. Como os desafios de gestão e de infraestrutura recrudescem, o meio técnico usualmente prefere adotar sistemas de sentidos no qual a natureza parece instável e pouco colaborativa com o modo de organização do espaço. Desse modo, tanto o contexto ambiental de excesso de água quanto o de escassez deste recurso são tratados como igualmente problemáticos e invocados em decretações de emergência que banalizam o estado de exceção administrativa local. Durante as chamadas “Operações-Verão" - época em que, originalmente, as defesas civis da região Sudeste ficavam em prontidão para atender a ocorrências relacionadas às chuvas -, tem havido decretação de emergência também em razão de escassez hídrica, justificativa que embasou sobremaneira a narrativa oficial nos períodos 2005-2006, 2007-2008, 2014-2015 e 2015-2016 (figura 4). 


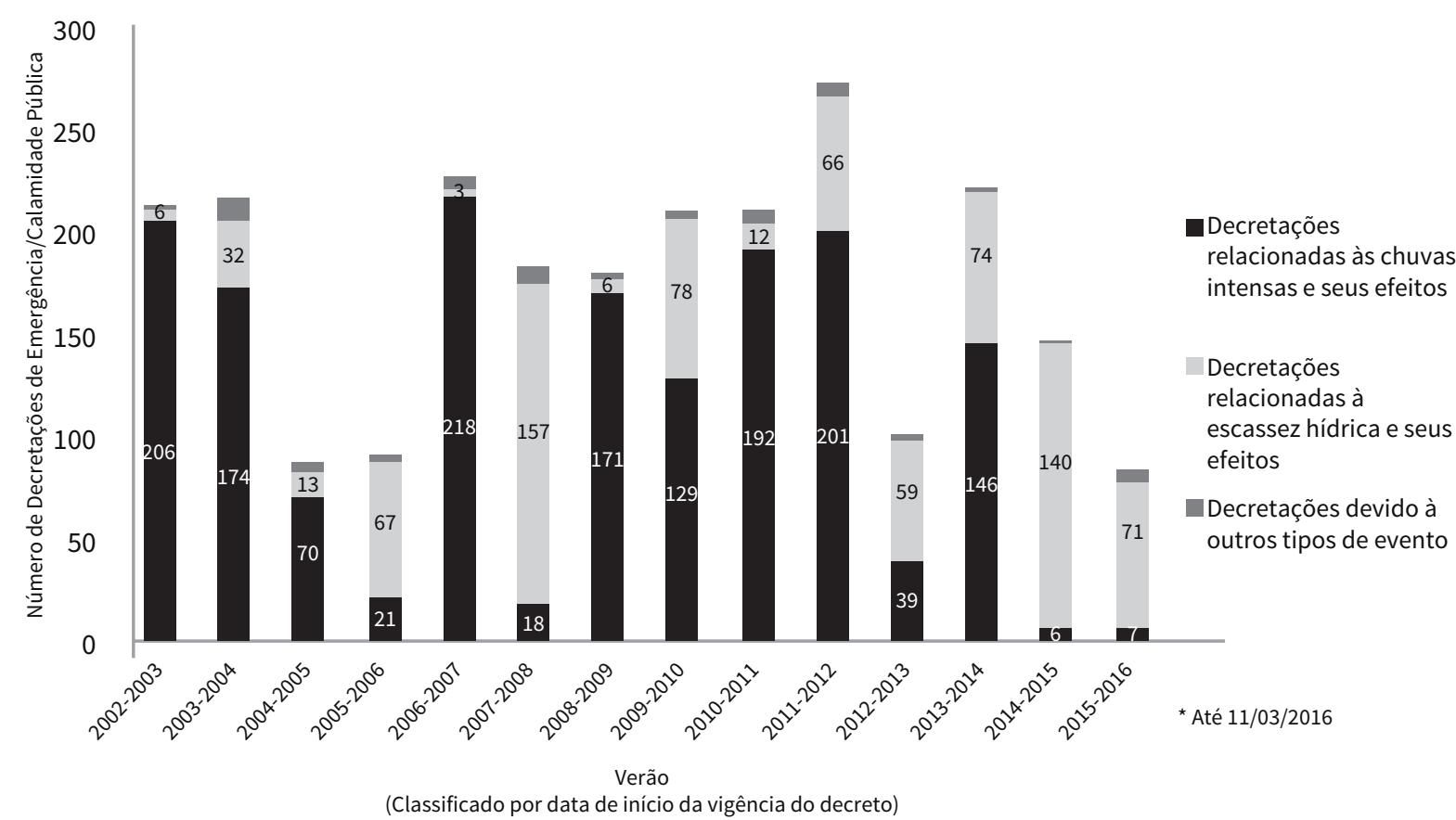

Figura 4: Decretações de Situação de Emergência ou Estado de Calamidade Pública na Região Sudeste nos períodos das "Operações-Verão" (Outubro - Março).

Fonte: sistematizado pelos autores a partir de informações da Secretaria Nacional de Proteção e Defesa Civil da República Federativa do Brasil, 2016 (http://www.mi.gov.br/web/guest/ reconhecimentos-realizados, atualização da página: 11/03/2016, acesso: 14/03/2016).

De um lado, quando o argumento oficial em torno das razões do desastre recai sobre as chuvas intensas ou acumuladas, como se fosse um problema estritamente meteorológico, deixa-se de notar que os estragos maiores se fazem notar onde a ausência do Estado é crônica. A destruição de moradias frágeis, a morte de pessoas indefesas e a necessidade de provimento de abrigos provisórios às famílias desabrigadas, não deriva apenas das chuvas - ou das enchentes e deslizamentos de terras às mesmas associadas -, mas da insuficiência de garantia dos direitos de cidadania. De outro lado, quando são os episódios de seca ou de estiagem prolongada os que aparecem no centro do discurso oficial sobre desastres, tudo passa como se se tratasse de um problema meramente climatológico a gerar crises hídricas. Contudo, tais crises denotam a composição política e econômica assimétrica entre multiusuários de água numa dada localidade e, na circunstância de escassez do recurso, os atores hegemônicos não aceitam uma repactuação da demanda, visando o atendimento das necessidades coletivas.

Quando postos nesses termos, o contexto ambiental de chuvas e estiagens é importante, mas não o principal desencadeador do desastre. Uma vez que não o seja, os desastres associados a esses eventos não deveriam ser chamados de "naturais", adjetivo que, no entanto, é utilizado abusivamente pelas autoridades governamentais e pelo meio técnico-operacional na decretação de emergência, escamoteando o cerne do problema. Observamos, 
de modo assistemático, que a imprensa brasileira assimila acriticamente essa terminologia, o que supomos que ocorra porque a mesma se nutre da narrativa científica dominante que, nesta linha de raciocínio, prescinde de produzir explicações sobre os processos sociopolíticos que transmutam a natureza em perigo/ameaça, sobretudo, para os grupos sociais historicamente em desvantagem. Essas narrativas alienantes obstruem a discussão de questões relativas à gestão pública da água, aos direitos sociais relacionados ao saneamento básico e à habitação popular e outras similares que subjazem a essa sucessão de desastres.

\section{Discussão}

Os números acima devem ser tomados com cautela, pois não são uma expressão exata da realidade concreta. Tanto são produzidos decretos de emergência sem que haja uma correspondência concreta com a situação do município quanto há desastres silentes, nos quais tragédias coletivas ocorrem sem que as autoridades locais tomem as providências devidas ou comuniquem a situação às instâncias superiores (Valencio, 2010).

Tais números indicam que os desastres que proliferam no Brasil e na região Sudeste poderiam, eventualmente, se tornar objetos nauseantes para a imprensa. A quase previsibilidade desses episódios poderia colocar em xeque seu status como acontecimento, no sentido jornalístico do termo; assim, seria as implicações do episódio para o público, aquilo que poderia voltar a despertar o interesse do mesmo pelo assunto (Martín-Barbero, 2002). Se a mídia, contudo, se aferra à velha fórmula, continuando a tratar cada ocorrência como algo inusitado, e não como parte integrante da cronicidade de problemas sociais multifacetados e correntes, a espetacularização do episódio adquire um tom ainda mais farsesco.

Em transição da cobertura de acontecimentos de ruptura - porém, nauseantes - para a averiguação de processos, matérias jornalísticas poderiam explorar os diferentes tempos envolvidos. Em termos do desencadeamento do perigo que é visto como inusitado, o tempo parece curto e, por vezes, transcorre num átimo: o momento do deslizamento de terra, do colapso da moradia, da explosão, da chuva forte, da pessoa carreada pela enxurrada. Mas, do ponto de vista de quem é confrontado com tais perigos e sem contar com uma proteção condizente, as perdas e danos humanos e materiais sofridos, representam o tempo largo de uma vida ceifada; de uma trajetória de trabalho marcada por dificuldades e incertezas que inviabilizam a recuperação daquilo que foi perdido; de dívidas contraídas em vários prazos para viabilizar o acesso a bens vitais e sociais danificados; de experiências pessoais significativas contidas em objetos de memória destruídos, entre outros prejuízos.

A pesquisa sociológica de base empírica sobre casos emblemáticos de desastres no Brasil pode fornecer novas dimensões sociopolíticas que os números oficiais não exprimem. Uma delas é sobre a regularidade da forma aviltante e violenta como as medidas técnicas de reabilitação têm sido prestadas aos grupos sociais mais severamente afetados nos desastres. Há reiteradas situações de prolongamento de constrangimento moral e sofrimento emocional em viver provisoriamente às custas de parentes ou em abrigos provisórios sob os regramentos de terceiros (Valencio, Siena \& Marchezini, 2011). Outra dimensão se refere aos problemas de protelamento, distorção de critérios e omissão pública, em relação às medidas recuperativas, suscitando com que os sobreviventes mais afetados, como famílias desalojadas e desabrigadas, vivam em incertezas relacionadas à garantia de seus direitos de moradia, de recuperação de bens móveis e meios de trabalho, assim como no concernente a informação sobre parentes e vizinhos desaparecidos no episódio (Valencio, 2012; 2014). 
Critérios adotados conjuntamente por órgãos de defesa civil e de assistência social têm respaldado uma interação técnica recorrentemente insensível para com os grupos afetados, desprezando-se a necessidade de escutar as queixas dos mesmos (Siena, 2013). Assim, os técnicos evitam ter contato com as razões mais profundas das discordâncias entre aquilo que pensam ser o melhor para tais grupos e aquilo que estes grupos pensam que seja o melhor para si mesmos. Conflitos e confrontos com autoridades ocorrem quando tais grupos tornam-se objeto de práticas de "remoção" sob reforço policial; quando clamam pela preservação da integridade de suas moradias que são alvo de demolição sob ordens da defesa civil; quando repudiam a forma de gestão de abrigos provisórios para onde são levados; quando cobram soluções de moradia que tardam a ser providenciadas; enfim, quando reivindicam que o Estado pare de tratá-los de uma forma desumana (Siena, 2013); (Vargas, 2015); (Valencio, 2014). Nesse particular, são muito comuns as matérias jornalísticas que assumem a visão técnica e contribuem para a condenação social dos grupos socialmente marginalizados. Num sentido oposto, quando os desastres envolvem extratos socioeconômicos superiores, os grupos afetados ganham maior espaço midiático para vocalização de suas queixas.

Uma ilustração dessas polarizações valorativas é a da cobertura do desastre ocorrido no Morro de Bumba, em Niterói/RJ, no ano de 2010 - episódio no qual foi constatado que o terreno ocupado por moradores de baixa renda tinha sido um antigo lixão, no qual morreram 48 pessoas e dezenas de moradias foram destruídas - frente ao caso do deslizamento de terra ocorrido em Angra dos Reis/RJ, no mesmo ano, no qual houve um foco midiático numa pousada para turistas, inserida ao pé de um terreno com acentuado declive em meio à Mata Atlântica. Sobre o caso do Morro do Bumba, a imprensa repercutiu de modo a apontar para a "inconsequência" dos moradores em se fixarem num terreno instável e num ambiente previamente degradado (UOL Notícias, 2010), enquanto a pesquisa psicossociológica identificou as violências sociais que haviam na resposta técnica a essa emergência (Valencio \& Darós, 2012). Já no caso do desastre em Angra dos Reis, o noticiário focalizou de modo positivo aspectos da subjetividade e da inserção social (temperamento, atividades rotineiras preponderantes, aspirações) de vítimas de classe social superior ao caso anterior, sendo inestimável a perda de suas vidas (IstoÉ, 2010).

Outra ilustração é a do caso do desastre ocorrido na região serrana fluminense, em janeiro de 2011, que afetou grupos de diferentes perfis espaciais e sociais, inseridos em áreas urbanas e rurais, residentes locais e turistas, ricos e pobres. Na ocasião, matérias faziam descrição de perdas e de providências governamentais (Revista Exame, 2011), enquanto o estudo sociológico, que fazíamos naquela ocasião, dava conta do abandono social em que viviam (Valencio, Siena \& Marchezini, 2011), e, somente mais recentemente, vemos que esse tema começa a vir à tona, como no questionamento jornalístico do número de mortes oficialmente divulgado à época (Canejo, 2015). Porém, a cobertura do falecimento de pessoas de classe social abastada, que estavam em turismo, em mansões do Vale do Cuiabá, distrito de Itaipava, município de Petrópolis, eram deploradas por parecer tão promissoras socialmente (O Dia, 2011).

É de notar que, quanto mais se responsabiliza as vítimas pela tragédia em que estão inseridas, menores se tornam os seus direitos a compensações (Drake, 2016). De outra parte, quando o core da narrativa midiática tem mesclado a explicação meteorológica ou climática, as responsabilidades públicas sobre o ocorrido somem de vista.

Essas fórmulas estão desgastadas e vem encontrando os seus limites diante de uma opinião pública que clama por interpretações midiáticas mais convincentes sobre a desafiadora realidade socioambiental brasileira. Por isso, desastres silentes, como a exposição e a morte homeopática de pessoas em situação de rua durante as 
enchentes, as ondas de frio e o recrudescimento das políticas higienistas (Granado, 2010), vem ganhando mais do que simples matérias jornalísticas de constatação dessa tragédia oculta (Valencio et al, 2008). Já há matérias que se orientam para apontar alternativas de humanização dos serviços de atendimento a esse grupo social (Piva, 2016). Quando uma das piores catástrofes brasileiras recentes - envolvendo o rompimento de uma barragem da empresa Samarco, no município de Mariana/MG, com consequências socioambientais devastadoras até a foz do Rio Doce, no estado do Espírito Santo - foi denominada como desastre "natural" pelo Governo Federal (Brasil, 2015), houve maior empenho jornalístico para abordar a complexidade do caso e o sofrimento social dos grupos afetados (Mendes, 2016).

A evolução cronológica e frequente das ocorrências no Brasil comprova que os desastres são, antes de tudo, processos que entrelaçam velhas e novas crises desestruturantes do espaço. Ademais, nelas, os estressores não se encontram apenas no evento em si, mas nos meios e interações que são desencadeados para lidar com situação (Ruf, 2014). Entender midiaticamente quanta violência há por detrás de práticas de apoio aos afetados é um caminho alvissareiro para problematizar as medidas de resposta e recuperação postas em curso. Assim, a abordagem direta aos afetados mereceria maior cuidado e sensibilidade profissional do jornalista do que sua preocupação com a imediata disponibilização da notícia (Jemphrey \& Berrington, 2000). Desastres são acontecimentos que perturbam o mundo sensível e, assim, põem à prova o habitus; estes dizem respeito a um princípio de ação, individual ou coletiva, baseado numa forma específica de apreensão da realidade (Thiry-Cherques, 2006). Portanto, não é apenas o mundo externo que desmorona para os sobreviventes, mas o seu sistema de sentidos do mundo, que precisa ser retrabalhado para lidar com a situação e procurar novos nexos para seguir adiante. Há um tempo subjetivo e social envolvido nessa empreitada, o qual, não raro, é interrompido pelo assédio impiedoso da imprensa. Seria muito oportuno que o resultado dessa interrupção - isto é, as matérias jornalísticas produzidas com as informações colhidas das pessoas em sofrimento - não incrementasse os riscos de desfiliação social das mesmas.

\section{Conclusões}

Desafortunadamente, não tem sido o jornalismo político e social aquele que se dedica ao tema do desastre. Se assim o fosse, talvez o qualificativo "natural", e outras classificações alienantes aplicadas à interpretação desses episódios, estariam sendo objeto de questionamento.

A literatura dedicada aos estudos de desastres sinaliza que, para além de atendimento aos ditames do mercado, os enredos midiáticos estereotipados costumam trazer, explícita ou sub-repticiamente, uma concepção de ordem social conservadora. Agindo como um filtro, o discurso midiático conservador impõe um tom acusatório sobre os grupos afetados nos desastres em áreas periféricas, insistindo na ideia de que a "ignorância", a "falta de percepção de risco" e a "irresponsabilidade" dos mesmos foi um dos fatores essenciais que ocasionaram a tragédia. Por um lado, essa insistência argumentativa, apoiada em "provas" - por exemplo, no fato de que uma família empobrecida construiu efetivamente a sua moradia em local suscetível à inundações ou deslizamentos - pode vir a escamotear convenientemente o processo, temporalmente mais abrangente, de continuadas injustiças e desigualdades sociais que levam a essa "opção" individual. Por outro, a recorrente acusação midiática de que famílias insistem em morar nas ditas "áreas de risco", não encontra similar esforço em denunciar, como origem desses desastres, as políticas públicas insuficientes que resultam na precariedade de espaços densamente povoados. 
Essa seletividade do foco da notícia é um traço da posição não neutra que os meios de comunicação ocupam no campo dessas crises e que debilita os recursos de voz daqueles que sofrem aquela situação e lutam por justiça ambiental. $\mathrm{O}$ desastre muitas vezes é tratado como uma anormalidade dentro da normalidade da degradação social, onde estão as raízes do problema (Cottle, 2014). Seria, assim, muito providencial que a mídia pudesse desviar um pouco seu foco dos fenômenos naturais para que a tessitura sociopolítica de produção de espaços suscetíveis fosse explorada mais a contento. Aquilo que existe no meio social, em termos de estruturas de autoridade e das instituições, explicaria muito melhor os desastres e, portanto, daria melhores indicações de como se enfrentar tais crises (Quarantelli, Lagadec \& Boin, 2007), o que seria uma contribuição jornalística mais louvável e oportuna.

Os estudos sociológicos têm focalizado as práticas de violência institucional contra os grupos afetados nos desastres, mas nos parece que os meios de comunicação fogem dessa questão. Talvez, porque o treinamento técnico que repórteres recebam para ter um acesso seguro a cenários ditos de risco possa estar sob o julgo de acordos tácitos em torno da manutenção de uma visão acrítica sobre esse problema.

Os resultados da pesquisa documental sobre os decretos de emergência no Brasil nos últimos anos, aqui expostos, indicam que nada há de inusitado nos desastres. A singularidade de cada crise aguda esconde a cronicidade da situação em geral, o que poderia ser um instigante objeto de um jornalismo crítico e socialmente compromissado.

Se temos uma forte impressão de que os meios de comunicação formais assumem um papel predominantemente conservador na amplificação dos desastres - o que poderia ser objeto de estudos futuros em comunicação -, também supomos que possam atuar na direção oposta; isto é, serem agentes difusores de explicações alternativas, capazes de mobilizar outras opiniões e reflexões no assunto. Esperamos que a contribuição sociológica aqui fornecida possa ser uma pista útil para esse propósito.

\section{Referências}

1. Acselrad, H. (2002). Justiça ambiental e construção social do risco. Anais do XIII Encontro da ABEP (pp. 1-19). Ouro Preto: Associação Brasileira de Estudos Populacionais - ABEP.

2. Acserald, H. (2006). Tecnologias sociais e sistemas locais de poluição. Horizontes Antropológicos, 12(25), 117-138.

3. Acselrad, H. (2014). A crítica do 'ambiente' ao ambiente da crítica. Antropolítica: Rev. Contemporânea de Antropologia, 36(1), 27-47.

4. Acselrad, H. (2015). Vulnerabilidade social, conflito ambiental e regulação urbana. O Social em Questão, $1(33), 57-68$.

5. Alexander, D. (2005). An interpretation of disasters in terms of changes in culture, society and international relations. In R. Perry and E.L. Quarantelli (Eds.). What is a disaster? New answers to old questions (pp. 25-38). Newark: International Research Committee on Disasters.

6. Alexander, D. (2014). Social media in disaster risk reduction and crisis management. Sci Eng Ethics, 20(3), 717-33. doi: 10.1007/s11948-013-9502-z

7. Bauman, Z. (2011). Vida em fragmentos: sobre a ética pós-moderna. Rio de Janeiro: Zahar Editora. 
8. Alves Filho, F., Villaméa, L., Magro, M., \& Frutoso, S.G (2010). Devastados pela fúria da natureza. IstoÉ. pp.1-8. Retrieved from http://www.istoe.c om.br/reportagens/38879_DEVASTADOS+PELA+FURIA+DA+NATUREZA

9. Amaral, M.F. (2015). Fontes testemunhais, autoridas e experts na construção jornalística das catástrofes. Líbero, 18(36), 43-53. Retrieved from http://casperlibero.edu.br/wp-content/uploads/2015/12/Marcia-Franz.pdf

10. Balza, G. (2008,16 de dezembro). Chuva em Santa Catarina mata mais de 120 pessoas; tragédias naturais castigam vários pontos do mundo. UOL Notícias. Retrieved from http://noticias.uol.com.br/especiais/retrospectiva- 2008/ultnot/2008/12/16/ult7037u9.jhtm

11. Beck, U. (1999). World risk society. Cambridge and Malden: Polity Press.

12. Biernacki, W. (2013). Mass media and natural disasters. In P. T. Bobrowsky (Ed.), Encyclopedia of Natural Hazards (pp. 655-657). New York: Springer. doi: 10.1007/978-1-4020-4399-4_228

13. Boin, A., \& t'Hart, P. (2007). The crisis approach. In H. Rodríguez, E. L. Quarantelli, \& R. R. Dynes (Eds.), Handbook of Disaster Research (pp.42-54). New York: Springer.

14. Bourdieu, P. (2004). O poder simbólico. Rio de Janeiro: Bertand Brasil.

15. Brasil. Ministério da Integração Nacional (2000). Política Nacional de Defesa Civil. Brasília: Secretaria Nacional de Defesa Civil.

16. Brasil. Presidência da República. Decreto nº. 8572, de 13 de novembro de 2015. Diário Oficial da União, seção 1, edição extra, 13/11/2015. Retrieved from http://pesquisa.in.gov.br/imprensa/jsp/visualiza/index. jsp?jornal=1000\&pagina=1\& data=13/11/2015

17. Bullard, R.D. (2006). Varridos pelo furacão Katrina: reconstruindo uma 'nova'Nova Orleans usando o quadro teórico da justiça ambiental. In S. Herculano, \& T. Pacheco (Eds.), Racismo Ambiental (pp.126-147). Rio de Janeiro: FASE.

18. Canejo, A. (2015, 10 de agosto). No de vítimas em tragédia no RJ pode ser dez vezes maior, dizem entidades. G1Região Serrana. Retrieved from http://g1.globo.com/rj/regiao-serrana/noticia/2015/08/entidades-apontam-subnotificacao-de-vitimas-da-tragedia-de-2011-na-serra.html

19. Cardoso, A. L. (2006). Risco urbano e moradia: a construção social do risco em uma favela do Rio de Janeiro. Cadernos IPPUR, XX (1), 27-48.

20. Cortês, G. (2005). Vulnerabilidad social y expresiones del desastre en el distrito de Pochutla, Oaxaca. In V. García-Acosta (Ed.), La construcción social del riesgo y el huracán Paulina (pp.35-152). México DF: CIESAS.

21. Cottle, S. (2014). Rethinking media and disasters in a global age: what 's changed and why it matters. Media war \& conflict, 7(1), 3-22. doi: 10.1177/1750635213513229

22. Das, V. (1995). Critical events: an anthropological perspective on contemporary India. New Delhi: Oxford University Press.

23. Das, V., \& Poole, D. (2008). El Estado y sus márgenes: etnografias comparadas. Cuadernos de Antropologia Social, 27, 19-52.

24. Drake, P. (2016). Multiple visions of Indonesia's mud volcano: understanding representations of disaster across discursive settings. Disasters, 40(2), 346-364. doi: 10.1111/disa.12145 


\section{DISERTACIONES}

ESTUDIOS

Anuario electrónico
ISSN: $1856-9536$

Doi: http://dx.doi.org/10.12804/revistas.urosario.edu.co/disertaciones/a.479.1

Volumen 10, Número 2 / Julio-diciembre 2017

Versión PDF para imprimir desde

http://revistas.urosario.edu.co/index.php/disertaciones

25. Folha de São Paulo (20107 de outubro). Em três dias, número de mortos no Rio supera o de tragédia em SC. Folha de S. Paulo. Retrieved from http://www1.folha.uol.com.br/cotidiano/2010/04/717751-em-tres-dias -numero-de- mortes-no-rio-supera-o-de-tragedia-em-sc.shtml

26. Folha de São Paulo (20115 de novembro). Defesa Civil vai instalar alertas para chuvas na região serrana do Rio. Folha de S. Paulo. Retrieved from http://www1.folha.uol.com.br/cotidiano/2011/11/1002130-defesacivil-vai-instalar-alerta-para-chuvas-na-regiao-serrana-do-rio.shtml

27. Fritz, C.E. (1961). Disaster. In R. K. Merton, \& R. A. Nisbet (Eds), Contemporary social problems (pp. 651-694). New York: Harcourt.

28. G1 (2010a, 1 de setembro). Desastres naturais marcam seis primeiros meses de 2010. G1. Retrieved from http:// g1.globo.com/mundo/noticia/2010/07/desastres-naturais-marcam-seis-primeiros-meses-de-2010.html

29. G1 (2010b, 29 de setembro). Chega a 37 o Número de mortos pela chuva em Alagoas. G1. Retrieved from http://g1.globo.com/brasil/noticia/2010/06/chega-37- o-numero-de-mortos-pela-chuva-em-alagoas.html

30. Gaitán, J., Lozano, C., \& Piñuel, J. (2013). Confiar em la prensa o no: un método para el estudio de la construción midiática de la realidade. Salamanca: Ed. Comunicación Social.

31. Iqbal, M., Ali F., Khursheed, M., \& Saleem S. (2014). Analysis of role of media in disaster reporting in Pakistan. European Scientific Journal, special edition 1, 570-5. Retrieved from http://eujournal.org/index.php/esj/ article/view/3676

32. Jemphrey, A., \& Berrington, E. (2000). Surviving the media: Hillsborough, Dunblane and the press. Journalism Studies, 1(3), 469-483. doi: 10.1080/14616700050081786

33. Kasperson, R. E., Renn, O., Slovic, P., Brown, H. S., Emel, J., Goble, R., Kasperson, J. X., \& Ratick, S. (1988). The social amplification of risk: a conceptual framework. Risk Analysis, 8, 177-187. doi: 10.1111/j.15396924.1988.tb01168.x

34. Marchezini, V. (2014). Campos de desabrigados: a continuidade do desastre. São Carlos: RiMa Editora.

35. Martín-Barbero, J. (2002). Ofício do cartógrafo: travessia latino-americana da comunicação nacultura. São Paulo: Edições Loyola.

36. Mendes, G. (2016, April 04). Identidades rompidas. O Estado de S. Paulo, Retrieved from http://m.alias. estadao.com.br/noticias/geral,identidades-rompidas, 10000048231

37. O Dia (2011, 9 de dezembro). Filhos de empresário morrem soterrados em mansão na Região Serrana. 0 Dia, p.1. Retrieved from http://odia.ig.com.br/portal/rio/filhos-de-empres \%C3 \%Alrio-morrem-soterrados-em-mans \%C3 \%A3o-na-regi \%C3 \%A3o-serrana-1.398366

38. O Estado de S. Paulo (2016, 12 de março). SP tem 88 municípios com risco de desastres por deslizamentos. O Estado de S. Paulo. Retrieved from http://sao- paulo.estadao.com.br/noticias/ geral,sp-tem-88-municipios-com-risco-de-desastre- por-deslizamentos, 10000020842

39. Oliver-Smith, A. (2006). Disasters and forced migration in the 21st century. Undestanding Katrina Essay Forum: perspectives from the social sciences, [online]. Social Science Research Council, New York. Retrieved from http://understandingkatrina.ssrc.org/Oliver-Smith/

40. Piva, N. (2016, 7 de junho). Em Paris, os comerciantes ofertam comida e serviços de graça para moradores de rua. Gazeta do Povo. Retrieved from http://www.gazetadopovo.com.br/vida-e-cidadania/futuro-das- 
cidades/em-paris- comerciantes-ofertam-comida-e-servicos-de-graca-para-moradores-de-rua- eg5b8pwgbpfs2tj02i09hytyw

41. Quarantelli, E. (1989). The social science study of disasters and mass communication. In L. M. Walters, L. Wilkins, \& T. Walters (Eds.), Bad Tidings: Communication and Catastrophe (pp. 1-19). Hillsdale: Lawrence Erlbaum Associates.

42. Quarantelli, E. (2005). A social science research agenda for disasters of the 21st century: theoretical, methodological and empirical issues and their professional implementations. In R.W.Perry, \& E.L. Quarantelli (Eds), What is a Disaster? New Answers to Old Questions (pp. 325-396). Bloomington: International Research Committee on Disasters and Xlibris.

43. Quarantelli, E., Lagadec, P., \& Boin, A. (2007). A heuristic approach to future disasters and crisis: new, old, and in-between types. In H. Rodriguez, E. L. Quarantelli, \& R. R. Dynes (Eds.), Handbook of disaster research (pp. 16-41). New York: Springer.

44. Revista Exame (2011, 14 de janeiro). Tragédia já é o maior desastre natural do Brasil. Retrieved from http:// exame.abril.com.br/mundo/noticias/tragedia-ja-e-o- maior-desastre-natural-da-historia-do-brasil

45. Roca, A. (2014). Trajetórias, memórias e silêncios de um país telúrico: a propósito dos saques logo após o terremoto de 2010 na cidade de Concepción, Chile. In N. Valencio, \& M. S. (Eds.), Sociologia dos Desastres: Construção, Interfaces e Perspectivas (Vol 4) (pp. 27-46). São Carlos: RiMa Editora.

46. Roze, J. P. (2016). Sistema, entropía y catástrofe. Cadernos de Trabalho da Rede Waterlat- Gobacit, 3(1), 6-25.

47. Ruf, B. (2014). Destroços e traumas: embasamentos antroposóficos para intervenções com a pedagogia de emergência. São Paulo: Editora Antroposófica.

48. Scanlon, J. (1996). Not on the record: disasters, records and disaster research. International Journal of Mass Emergencies and Disasters, 14(3), 265-280.

49. Scanlon, J. (2007). Unwelcome irritant or useful ally? The mass media in emergencies. In H. Rodríguez, E. L. Quarantelli, \& R. R. Dynes (Eds.), Handbook of Disaster research (431-429). New York: Springer.

50. Scanlon, J. (2011). Research about the mass media and disaster: never (well hardly ever) the twain shall meet. In J. R. Detrani (Ed.), Journalism Theory and Practice (pp.233-269). Binghamton: Apple Academic Press.

51. Scanlon, J., \& Alldred, S. (1982). Media coverage of disasters: the same old story. In B.G. Jones, \& M. Tomazevic (Eds.), Social and Economic Aspects of Earthquakes (pp.363-375). Ithaca: Institute for Testing and Research in Materials and Structures Cornell University and Ljubljana. Retrieved from http://www.eird. org/bibliovirtual/capra/pdf/eng/doc13422/doc13422-contenido.pdf.

52. Shah, A. (2005). Media and natural disasters. Global Issues. Retrieved from http://www.globalissues.org/ article/568/media-and-natural-disasters.

53. Siena, M. (2013). A política de assistência social em contexto de desastres relacionados às chuvas: um estudo sobre o município de Ribeirão Preto/SP. In N. Valencio, \& M. Siena (Eds.), Sociologia dos Desastres: Construção, Interfaces e Perspectivas no Brasil (pp. 38-61). São Carlos: RiMa Editora.

54. Solano, P. (2009, 9 de janeiro). Blumenau proíbe volta a áreas de deslizamento até Abril. Folha de S. Paulo. Retrieved from http://www1.folha.uol.com.br/cotidiano/2009/01/488474-blumenau-proibe-volta-aareas-de-deslizamento-ate-abril.shtml. 


\section{DISERTACIONES}

ESTUDIOS

Anuario electrón ico

Doi: http://dx.doi.org/10.12804/revistas.urosario.edu.co/disertaciones/a.4791

Volumen 10, Número 2 / Julio-diciembre 2017

Versión PDF para imprimir desde

http://revistas.urosario.edu.co/index.php/disertaciones

55. Sorokin, P. (1942). Man and society in calamity: the effects of war, revolution, famine, pestilence upon human mind, behaviour, social organization and cultural life. New York: E. P. Dutton.

56. Thiry-Cherques, H. (2006). Pierre Bourdieu: a teoria na prática. RAP: Revista de Administração Pública, 40(1), 27-55. doi: 10.1590/S0034-76122006000100003

57. Tierney, K., Bevc, C., \& Kuligowsky, E. (2006). Metaphors matter: disaster myths, media frames, and their consequences in hurricane Katrina. Annals of the American Academy of Political Science, 604(1), 57-81. doi: $10.1177 / 0002716205285589$

58. UOL Notícias (2011, 8 de abril). Morro do Bumba, em Niterói, tinha 200 moradores, dizem bombeiros e prefeitura. UOL Notícias Cotidiano. Retrieved from http://noticias.uol.com.br/cotidiano/ultimas-noticias/2010/04/08/ para- bombeiros-e-prefeitura-morro-do-bumba-em-niteroi-rj-tinha-200-moradores. htm

59. Valencio, N., Pavan, B.J.C., Siena.M., Marchezini, V. (2008). Pessoas em situação de rua: estigmatização, desfiliação e desterritorialização. Revista Brasileria de Sociologia da Emoção, 7, 556-605.Retrieved from http://www.cchla.ufpb.br/rbse/NormaArt.pdf

60. Valencio, N. (2009). Da "área de risco" ao abrigo temporário: uma análise dos conflitos subjacentes a uma territorialidade precária. In N. Valencio, M. Siena, V. Marchezini, J.C. Gonçalves. Sociologia dos Desastres: Construção, Interfaces e Perspectivas no Brasil (Vol 2) (pp. 34-47). São Carlos: RiMa Editora.

61. Valencio, N. (2010). O desastre como locus da barbárie: apontamentos sobre o caso brasileiro. In N. Valencio E.A. Paula, A.C. Witkoski. Processos de Territorialização e Identidades Sociais (Vol. I) (pp.299-321). São Carlos: RiMa Editora.

62. Valencio, N., Valencio, A. (2011). Os desastres como indícios da vulnerabilidade do Sistema Nacional de Defesa Civil: o caso brasileiro. Territorium, 18, 147-156. Retrieved from http://www.uc.pt/fluc/nicif/riscos/ Documentacao/Territorium/T18_artg/Norma_Val encio.pdf

63. Valencio, N., Siena, M., \& Marchezini, V. (2011). Abandonados nos desastres: Uma Análise Sociológica de Dimensões Objetivas e Simbólicas de Afetação de Grupos Sociais Desabrigados e Desalojados. Brasília: Conselho Federal de Psicologia.

64. Valencio, N., \& Darós, L.E.S. (2012). Tragédia das águas em Niterói e a condição de abandono dos sobreviventes. In Valencio, N. (Ed.), Sociologia dos Desastres: Construção, Interfaces e Perspectivas no Brasil (Vol 3) (pp.230-256). São Carlos: RiMa Editora.

65. Valencio, N. (2012). Para além do 'dia do desastre'. Curitiba: Editora Appris.

66. Valencio, N. (2014). Tecnicismo e sofrimento social. Ciência e Saúde Coletiva, 19(9), 3631-3644. doi: 10.1590/1413-81232014199.06792014

67. Valencio, N. (2015). Desastres normais: das raízes aos rumos de uma dinâmica sociopolítica perversa. In A. Siqueira, N. Valencio, M. Siena, \& M. Malagodi (Eds.), Riscos de desastres relacionados à àgua: aplicabilidade de bases conceituais das Ciências Humanas e Sociais para a análise de casos concretos (pp. 79-120). São Carlos: RiMa Editora.

68. Vargas, D. (2015). Reino da necessidade versus reino dos direitos: desafios e impasses ao assistente social em contextos de desastres. In A. Siqueira, N. Valencio, M. Siena, \& M. Malagoli (Eds.), Riscos de desastres relacionados à àgua: aplicabilidade de bases conceituais das Ciências Humanas e Sociais para a análise de casos concretos (pp. 123-140). São Carlos: Rima Editora. 